\title{
Afşin-Elbistan Termik Santrali Çevresi Hafriyat Döküm Alanlarında Dikili Fidanların Kuruma Nedenleri Üzerine Araştırma
}

\author{
İsmail Özcan ${ }^{1, *}$, Cengiz Bahadıroğlu ${ }^{2}$, Hakan Bozdoğan ${ }^{3}$ \\ ${ }^{1-2}$ Kahramanmaraş Sütçü Imam Üniversitesi, Fen-Edebiyat Fakültesi, Biyoloji Bölümü, 46100, \\ Kahramanmaraş/Turkey \\ ${ }^{3}$ Ahi Evran Üniversitesi, Meslek Yüksek Okulu, Bitkisel ve Hayvansal Üretim Bölümü, 40100, \\ Kirşehir/Turkey
}

Özet

Afşsin Elbistan Termik Santrali çevresi hafriyat dökülmüş alanlarda toprak erozyonunu önlemek amaciyla 1987 y1lından başlayarak bugüne kadar 907 hektar araziye büyük çoğunluğunu çam (Pinus nigra) ve yalancı akasya (Robinia pseudoacacia)'nın oluşturduğu fidanlar dikilmiş ve son yıllarda söz konusu fidanlarda kurumalar (\%27) gözlenmiştir. Araştırma kapsamında, ağaçların kuruma nedenlerini saptamak amacı ile 2012-2013 yılları arasında toprağın fiziko-kimyasal yapısı, sıcaklık ve nem oranı, hava kirliliği ve zararlı böceklerin etkisi gibi faktörler incelenmiştir. Alınan toprak örneklerinde $\mathrm{pH}(8,5)$, kireç oranı $(\% 24,5)$ yüksek düzeyde, organik madde yönünden ise yoksun bulunmuştur. Toprak, kül-cüruf karışımından oluşmakla, bu karışımın da yüksek miktarda Ni, $\mathrm{Zn}, \mathrm{Pb}$ vs. gibi elementler kaydedilmiştir. Ayrıca kontrol arazilerle kıyaslandığında toprak sıcaklığının $1,5-1,7^{\circ} \mathrm{C}$ yüksek, nemliğin ise \% 5-7 oranında düşük olduğu gözlenmiştir. Santral bacalarından çıkan emisyonların bileşiminde $\mathrm{CO}_{2}, \mathrm{NO}_{\text {ve }} \mathrm{SO}_{2}$ içeren zehirli tozların bitki yapraklarında yanıklara neden olduğu, böyle yaprakların kuruyarak döküldüğü ve sonuçta ağaçların kuruduğu gözlenmiştir. Ağaçlandırılmış arazilerde 5 takıma ait toplam 9 zararlı böcek türü tespit edilmiş, ancak bunların da popülasyon düzeyi düşük olmakla fidanların gelişimine pek etki sağlamadığı tespit edilmiştir. Sonuç olarak fidanların kurumasının; toprağın kimyasal yapısı, hava kirliliği ve nem oranının düşük seviyede olmasından kaynaklandığı ihtimal edilmektedir.

Anahtar Kelimeler: Afşin-Elbistan Termik Santrali, Ağaçlandırılmış Arazi, Toprak

\section{A Research on the Causes Drying of Seedlings Planted in the Areas of Afşin- Elbistan Thermal Power Plant Environmental Excavation Casting Standing}

\begin{abstract}
In order to avoid soil erosion in the areas of Afşin-Elbistan Thermal Power Plant Environmental Excavation Casting Standing so far, pine (Pinus nigra) and black locust (Robinia pseudoacacia) planted to the 907 hectares terrain by starting in 1987. In recent years drying out $(27 \%)$ was observed in these seedlings. This research is aim to determine the cause drying of trees, between the years 2012-2013, physico-chemical structure and temperature-humidity of the soil, air pollution and the impact of factors such as harmful insects were examined. In the soil samples, $\mathrm{pH}(8,5)$, the amount of lime $(24,5 \%)$ were observed. Also, it was found to be lack in point of organic material. Besides, ash-slag mixture containing in the higher levels $\mathrm{Ni}, \mathrm{Zn}, \mathrm{Pb}$, etc. has been observed. Also, when it compared with control plots, soil temperature $1,5-1,7{ }^{\circ} \mathrm{C}$ high, while humudity $5-7 \%$ low has been observed. Emissions releasing from power plant chimneys composition contains $\mathrm{CO}_{2}, \mathrm{NO}$ and $\mathrm{SO}_{2}$. These toxic dust compounds created burns in plant leaves and caused to the drying of the leaves by pouring. Total, 9 harmful insect species belong to 5 Order have been identified in the wooded terrain but their population level that has been found a negligible effect on the seedlings in drying. As a result; drying of seedlings is thought to arise from the ecological factors such as soil chemical composition, the low level relative humidity of soil and air pollution.
\end{abstract}

Keywords: Afşin-Elbistan Thermal Power Plant, Wooded Land, Soil

*e-mail: ozcan_16bursa@hotmail.com 


\section{Giriş}

Günümüzde elektrik üretimi ekonomik ve sosyal kalkınmanın en önemli göstergelerinden biri olup insanların refah yaşamasına önemli katkı sağlamaktadır. Kullanılışlarına göre enerji kaynakları yenilenebilir (güneş, rüzgâr, jeotermal, hidrojen vs.) ve yenilemez (kömür, petrol, doğalgaz, uranyum) göre birincil (kömür, petrol, doğalgaz, güneş, rüzgar, nükleer) ve ikincil (elektrik, benzin, hava gazı, sıvılaştırılmış petrol gazı) enerji kaynaklarına ayrılır [1].

Ülkemizde termik santrallerle ilgili çok sayıda araştırmalar yürütülmekte olup ve bu çalışmalarda santrallerin önemi, ayrıca çevre sorunlarından bahsedilmektedir [2-9].

Zengin linyit yataklarının bulunuşu, kısa sürede ve düşük maliyetlerle inşa edilmesi gibi getirdiği avantajlardan dolayı termik santraller elektrik enerjisi üretiminde en çok tercih edilen işletmelerdir.

Ülkemizde halen 11 adet termik santral bulunmakta ve bunların arasında elektrik enerjisi üretim kapasitesine göre Afşin-Elbistan Termik Santrali birinci sıradadır.

Bu tesisin temelleri 1973 yllında atılmış ve 1984 yılında enerji üretimine başlamıştır. Santral A ve B ünitelerinden oluşmakta ve tam kapasite ile çalıştı̆̆ında zaman yılda yaklaşık 17 milyar MW elektrik üretmekte ve bu üretimi gerçekleştirebilmek için 16 milyon ton kömüre ihtiyaç duymaktadır [10].

Termik santralden kaynaklı çevre kirliliği etmenleri hava, toprak ve su kirliliğidir [11 ve 12].

Termik santralde kömürün yakılması ile içerisinde yanmayan inorganik maddeler kül olarak kalır ve küçük parçalar baca gazlarıyla birlikte dışarıya atılır. Ayrıca kömür yanarken sıcaklık $1500{ }^{\circ} \mathrm{C}$ erişmekte ve bu ısıda birçok elementler gaz haline dönüşmektedir. Özellikle $\mathrm{S}$ ve $\mathrm{N}$ oksitleşerek $\mathrm{NO}$ ve $\mathrm{SO}_{2}$ gazları oluşturur ve baca ile dışarı atılır. Yanma ünitesi atmosferdeki $\mathrm{N}_{2}$ gazıda $950{ }^{\circ} \mathrm{C}$ üzerinde sıcaklıkta NO dönüşür [13].

Akbay ve arkadaşları tarafından "Afşin-Elbistan Santrali'nin Neden Olduğu Çevre Kirliliğinin Ekonomik Analizi" başlığı altında yürüttüğü çalışmalar sonucu çevrenin kirlilik haritasını düzenlemiştir [14].

Ayrıca bazı araştırmacılar tarafından Afşin Elbistan Termik Santralinde oluşan küllerin tarım alanlarında yararlanma olanakları incelenmiş ve sonuçta bitki bünyesinde yüksek oranda ağır metal birikimine neden olduğu belirlenmiştir [15].

\subsection{Hafriyat Dökülmüş Alanlarda Ağaçlandırmanın Önemi}

Afşin-Elbistan Linyit İşletmesinde kömür havzadan çıkarılmadan önce toprağın humuslu tabakası alınır ve daha sonra döner kepçeli ekskavatörlerle $80 \mathrm{~m}$. derinliğe kadar kazılır, son olarak 80-120 m. arası derinlikten kömür çıkartılır. Kömür çıkarıldıktan sonra boşalan alanlara termik santralde oluşan külcüruf karışımı doldurulur ve yüzeyi daha önceden alınmış humuslu toprakla kapanır. Santral ünitelerinin tam kapasite ile çalışması durumunda günlük 11880 ton kül, 1306 ton cüruf oluştuğu ve buda yıl bazında 4276800 ton kül ve 470448 ton cüruf anlamına gelmektedir [16].

İşletmenin üretim faaliyetine başlamasından itibaren geçen 32 yıl arzında 9070 dönümden fazla boş alan kül-cüruf karışımı ve humuslu toprakla kapatılmıştır. Sonra 3-4 yıl toprağın sıkışması beklenmiş ve üzerinde yaklaşık 2-3 m. aralıklarla çukurlar kazılmıştır. Çukurlara organik gübre atılmış ve içerisine 1-2 yıllık tüplü veya tüpsüz ağaç fidanları dikilmiştir. Fidanların kurumaması için yaz aylarında periyodik sulamalar yapılmış ve bu işlem 3-4 yıl devam ettirilmiştir. Daha sonra ise fidanların topraktan su ihtiyacı- 
nı karşılayacağı varsayılmıştır. İlk ağaçlandırma işlemine 1987 yılında başlanmış, 2012 yılına kadar toplam 510101 tüplü ve 233184 adet tüpsüz fidan dikilmiştir [16].

Fidan türlerinin çoğunluğunu iğne yapraklılar (Lübnan sediri (Cedrus libani) \%42, Karaçam ( $P i$ nus nigra) \%24, Boylu ardiç (Juniperus excelsa) \%1, Mavi ladin (Picea punges) \%1) ve az miktarını ise geniş yapraklılar Akasya (Acacia cyanophylla) \%20, Toros akçaağacı (Acer hyrcanum) \%3, Çiçekli dişbudak (Fraxinus ornus) \% 2, Batı çınarı (Platanus occidentalis) \%1, Yalancı akasya (Robinia pseudoacacia) $\% 1$ ve diğerleri $\% 5$ oluşturmaktadır.

Ağaçlandırılmış araziler biyoçeşitlilik yönünden önem taşımakta olup çeşitli böcek türleri, sürüngen, kuş ve memeli hayvanlar için doğal bir yaşam alanına dönüşmüştür. Özellikle böcek türlerinin çoğalması diğer hayvanlarında bu yeşillik alanlarda barınma riskini artırmaktadır. Ağaçlandırmanın diğer önemli faydalı yönü de yüzey erozyonunu engellemesidir.

Bilimsel araştırmalarda ağaçlandırılmış arazilerin durumu ve fidanların gelişimi konusunda kayıtlara rastlanmamıştır. Oysa yapılan gözlemlerle fidanlar arasında belli bir oranda kurumaların (ortalama \%24) olduğu gözlenmektedir ve Linyit İşletmesi Müdürlüğünün istemi üzerine yürütülen bu çalışmada amaç fidanların kuruma nedenlerinin araştııılması ve önleyici tedbirlerin alınmasına yöneliktir.

\section{Materyal ve Metot}

Afşin-Elbistan Termik Santrali hafriyat dökülmüş alanlarda fidanların kuruma nedenlerini araştırmak amacıyla 2012-2013 yıllarında arazi çalışmaları yürütülmüş ve sahalar fidanların dikim yıllarına göre (27-20, 20-15, 15-10, 10-5, 5-1 yıl bundan önce olmakla) 5 parsele ayrılmıştır. Bu parsellerde fidanların kuruyabileceğine ihtimal veren bazı ekolojik faktörler; toprağın fiziko-kimyasal yapısı, hava ve toprağın sıcaklığı, nemliği, hava kirliliği ve böcek popülasyonu gibi bazı parametreler incelenmiştir.

Ağaçlandırılmış arazilerde toprağın fiziko kimyasal yapısını belirlemek için farklı parsellerde çam ve yalancı akasya kökleri $30 \mathrm{~cm}$. derinliğe kadar kazılmış ve örnekler alınmıştır. Ayrıca kontrol amaçlı olarak yakındaki Çomüdüz ve Alemdar köylerinden toprak numuneleri toplanmıştır. Örnekler laboratuara getirilmiş, oda sıcaklığında kurutulmuş ve sonra 2 mm'lik elekten geçirilerek plastik torbalara aktarılmıştır.

Toprak örneklerinde Demiralay tarafindan, önerilen yöntemle, saturasyon işlemleri yapılmış ve saturasyon ekstraktının elektriksel iletkenliği metre (WTW microprocesser conduktivity LF 537) ile ölçülerek tayin edilmiştir [17-18].

Toprağın $\mathrm{pH}$ oranını belirlemek için Black, yöntemine uygun olarak toprak örnekleri 2 mm'lik elekten geçirilmiş, $100 \mathrm{~g}$. tartılarak saturasyon çamuru hazırlanmıştır. Sature hale gelen toprak örneği bir gece ağzı kapalı olarak bekletilmiş, pH metre ile pH'ları ölçülmüştür [19].

Ayrıca toprağın kireç Loeppert ve Suarez; organik madde içeriği Jackson; değişebilir potasyum Helmke ile Sparks ve yarayışlı fosfor miktarı ise Kuo taraflarından önerilen yöntemlerle tespit edilmiş̧ir [20-23].

Toprak örneklerindeki anorganik elementler ve bileşimlerinin tayini Loeppert ve Inskeep tarafından önerilen metotlarla yapılmış ve $\mathrm{Cr}, \mathrm{Ni}, \mathrm{Zn}$ vb. elementlerin konsantrasyonları PE3110 Atomik Absorbsiyon Spektrofotometre ile belirlenmiştir [24]. 
Topraktaki nem oranını belirleyebilmek için çam, yalancı akasya ağaçları kökleri burgu aleti ile $30 \mathrm{~cm}$. derinlikte kazılmış ve toprak örnekleri alınmıştır. Örnekler saklama kaplarına aktarılmış ve içerisindeki rutubetin kaybolmaması için ağzı sıkıca kapatılmıştır. Kontrol olarak Çomüdüz ve Alemdar köylerinden de örnekler alınmıştır. Laboratuarda toprak örnekleri hassas terazide $100 \mathrm{~g}$. ağırlığında tartılııs ve hava- kuru toprak ağırlığı belirlenmiş, daha sonra tartılan örnekler etüv cihazında $105^{\circ} \mathrm{C}$ 'de 24 saat süre ile 1sıtılarak içerisindeki suyun buharlaşması sağlanmıştır. 24 saatten sonra etüv aletinden alınmış hassas terazide tekrar tartılarak firın kuru toprak ağırlı̆̆ı miktarı tespit edilmiştir. Sonuçta toprağın nemlik oranı aşağıdaki formülle hesaplanmıştır [25].

$$
\% \text { Nem }=\frac{\text { Hava kuru ağılık }- \text { Fırın kuru ağırlık }}{\text { Fırın kuru ağırlık }} \times 100
$$

Örnekler alındığı sırada toprağın sıcaklığı da ölçülmüş ve bu amaçla cıvalı termometre kullanılmıştır. Ayrıca Elbistan Meteoroloji Müdürlüğünden 2012-2013 yıllarına ait meteoroloji veriler alınmış (sıcaklık, nemlik, rüzgâr yönü vs.) ve değerlendirilmiştir.

Atmosfer kirliliğini belirlemek amacı ile Afşin-Elbistan Termik Santrali Müdürlüğünden günlük ve yıllık havaya karışan toz, zararlı gaz ve emisyonların miktarıyla ilgili veriler alınmış, ayrıca ağaçlandırılmış araziden geçen hâkim rüzgârların yönü ve hava kirliliğinin fidanlara etkisi araştırılmıştır.

Böcek faunası ve popülâsyonunu belirlemek amacıyla farklı gelişim dönemindeki bireyler fidanların çeşitli ( yaprak, dal, gövde ve kök) kısımlarından atrap, pense yardımı veya elle toplanmış, laboratuarda ergin bireyler oluşuncaya kadar beslenmiştir. Sonuçta ergin bireylerin tür teşhis işlemi yapılmıştır. Ayrıca böceklerin arazide sıklığı ve bazı biyolojik özellikleri kayıt edilmiştir.

\section{Bulgular}

Ağaçlandırılmış alanlarda toprağın fiziko kimyasal yapısıyla ilgili veriler Tablo 1'de belirtilmiştir. Tahlil sonuçlarına göre fidanların dikim yılına bağlı olmamaksızın topraktaki pH'ın miktarı ortalama 8,5 ve kontrol arazilerde ise 7,4 olarak kayıt edilmiştir. Ağaçlandırılmış arazilerde $\mathrm{pH}$ değerinin köy topraklarıyla kıyaslandığında düşük olduğu, orta alkali sınıfına girdiği ve orta alkali $\mathrm{pH}$ 'lı topraklarda da iyon dengesi bozulması sonucu bitkiler tarafindan gerekli olan bazı elementlerin ( $\mathrm{Ca}$, $\mathrm{Mg}$ ve $\mathrm{K}$ ) topraktan yeterli düzeyde alınmamasına ortam oluşturmaktadır [26].

Ayrıca ağaçlandırılmış arazilerden alınan toprak örneklerinde kireç oranı \%19,39-25,74, kontrol alanlarda ise \%7,28-10,25 arasında değişmiştir. Kireç oranının kontrol alanlara göre yüksek olmasının nedeni hafriyat alanlarına kireçli ve humuslu toprakların karıştırılarak dökülmesinden kaynaklandığ ihtimal edilmektedir. Toprağın yapısı, anorganik ( $\mathrm{Ni}, \mathrm{Zn}, \mathrm{Pb}$ miktarı) ve organik içeriği ile ilgili diğer bilgiler Tablo 1'de sunulmuştur.

Tablo 1'de görüldüğü gibi ağaçlandırılmış parseller ve kontrol toprak içeriğinde kimyasal elementlerin miktarı ve organik bileşiminde pek farklılıklar gözlenmemektedir. 
Tablo 1. Toprak fiziko-kimyasal analiz sonuçları

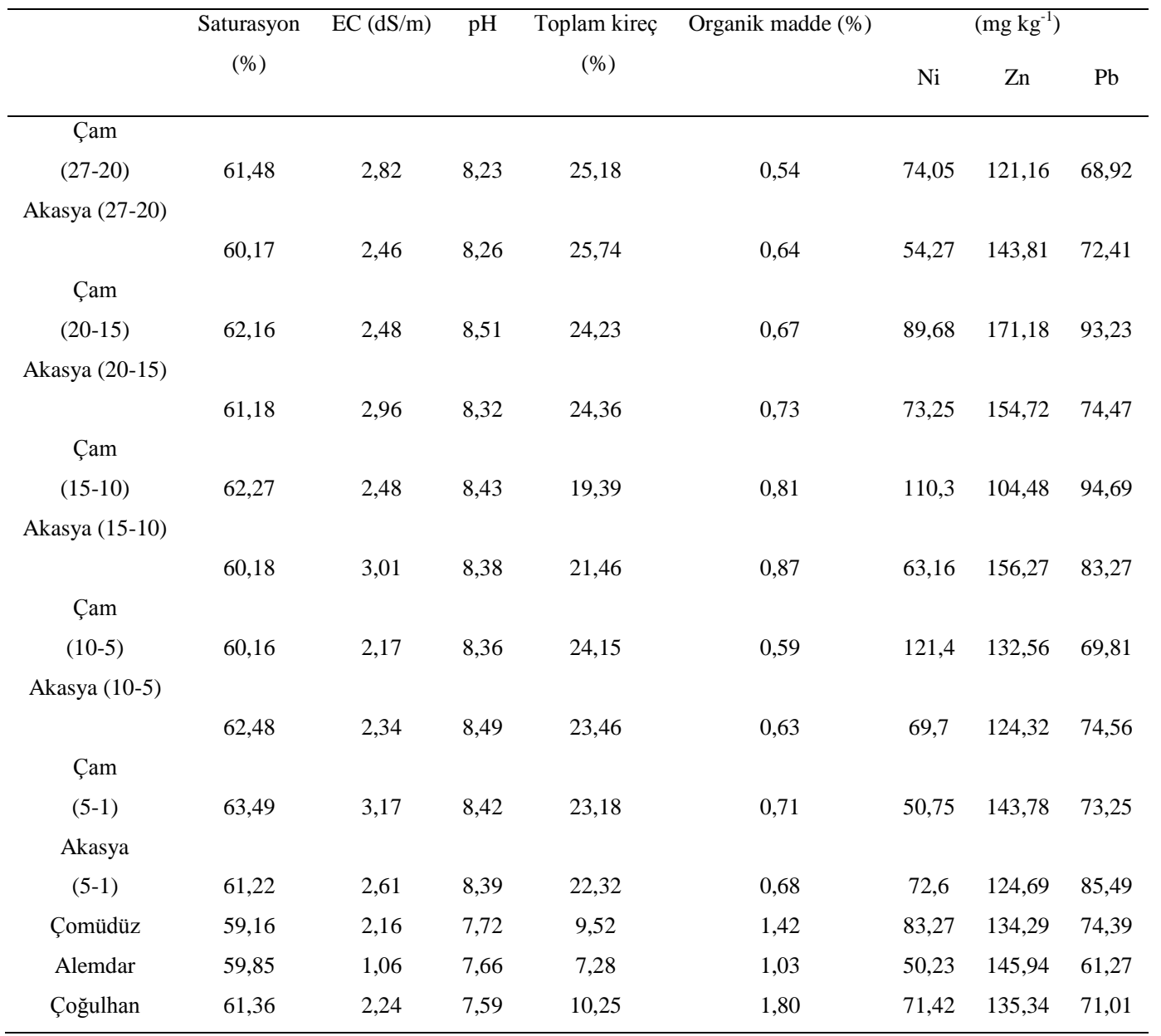

Fidanlar dikilmiş parsellerde toprağın sıcaklığı ve nemliği $30 \mathrm{~cm}$. derinlikte ölçülmüş, çam (Pinus nigra) fidanları dikilmiş topraklarda (dikim yılları dikkate alınmaksızın) en yüksek sıcaklık $24,3{ }^{\circ} \mathrm{C}$ (Ağustos ayı) ve en düşük ise $4,6^{\circ} \mathrm{C}$ (Ocak ayı) olmuştur. Yalancı akasya (Robinia pseudoacacia) dikilen arazilerde ise en yüksek sıcaklık $23,8^{\circ} \mathrm{C}$ (Ağustos ay1), en düşük sıcaklık ise $5,2^{\circ} \mathrm{C}$ (Ocak ayı) olarak ölçülmüşsür.

Kontrol olarak Çomüdüz köyünde toprağın en yüksek sıcaklığı $21,4{ }^{\circ} \mathrm{C}$ (Temmuz ayı), en düşük ise 4,9 ${ }^{\circ} \mathrm{C}$ (Ocak ayı), Alemdar köyünde toprağın en yüksek sıcaklığ $21,2{ }^{\circ} \mathrm{C}$ (Temmuz ayı), en düşük ise $4,7^{\circ} \mathrm{C}$ (Ocak ayı) olarak tespit edilmiştir (Tablo 2).

Çam fidanlıklarında en yüksek nem değeri \%23,4 (Aralık ayı), en düşük ise \%17,7 (Haziran ayı), yalanc1 akasya alanlarında ise en yüksek nem \%22,5 (Aralık ayı), en düşük ise \%16,0 (Haziran ayı) olarak ölçülmüştür. Kontrol alanlarda (Çomüdüz ve Alemdar) ise bu rakamlar yukarıda belirtilen aylara göre $\% 32,4$ ve $\% 28,0$ olmuştur (Tablo 2).Sonuç olarak yazın köy topraklarında ortalama sıcaklık $2,4{ }^{\circ} \mathrm{C}$ düşük, nemlik ise $\% 9-10$ yüksek olduğu belirlenmiştir. Ağaçlandırılmış arazilerdeki toprak sıcaklığının yüksek ve nem oranının kontrol arazilerle (Çomüdüz ve Alemdar köyü) kıyaslandığında düşük olması büyük bir ihtimal ki toprağın yeterli derecede sıkışmaması ve kül içermesinden kaynaklanmaktadır. 
Tablo 2. Ağaçlandırılmış alanlar ve çevre köylerdeki toprakların sıcaklık ve nem oranı

\begin{tabular}{|c|c|c|c|c|c|c|c|c|}
\hline \multirow{3}{*}{$\begin{array}{c}\text { Ölçümlerin } \\
\text { yapıldığı aylar }\end{array}$} & \multicolumn{4}{|c|}{ Ağaçlandırılmış araziler } & \multicolumn{4}{|c|}{ Kontrol grubu } \\
\hline & \multicolumn{2}{|c|}{ Çam } & \multicolumn{2}{|l|}{ Akasya } & \multicolumn{2}{|c|}{ Çomüdüz } & \multicolumn{2}{|c|}{ Alemdar } \\
\hline & Sicaklık $\left({ }^{\circ} \mathrm{C}\right)$ & $\operatorname{Nem}(\%)$ & Sicaklık $\left({ }^{\circ} \mathrm{C}\right)$ & $\begin{array}{c}\text { Nem } \\
(\%)\end{array}$ & Sicaklık $\left({ }^{\circ} \mathrm{C}\right)$ & $\begin{array}{c}\text { Nem } \\
(\%)\end{array}$ & Sicaklık $\left({ }^{\circ} \mathrm{C}\right)$ & $\begin{array}{c}\text { Nem } \\
(\%)\end{array}$ \\
\hline Ocak & 4,6 & 21,4 & 5,2 & 21,5 & 4,9 & 30,4 & 4,7 & 30,9 \\
\hline Şubat & 5,7 & 20,8 & 7 & 20,8 & 5,2 & 29,7 & 6,1 & 30,4 \\
\hline Mart & 7,2 & 19,3 & 8,2 & 19,0 & 6,8 & 29,2 & 6,9 & 29,3 \\
\hline Nisan & 8,3 & 18,6 & 11,9 & 18,3 & 7,9 & 28,8 & 10,5 & 28,9 \\
\hline Mayıs & 12 & 18,0 & 15,3 & 17,4 & 13,4 & 28,6 & 14,2 & 28,2 \\
\hline Haziran & 15,4 & 17,7 & 20,4 & 16,0 & 20,9 & 28,0 & 20,2 & 28,0 \\
\hline Temmuz & 21,5 & 18,2 & 21,5 & 17,6 & 21,4 & 29,6 & 21,2 & 28,6 \\
\hline Ağustos & 24,3 & 19,6 & 23,8 & 18,4 & 18,9 & 30,2 & 17,8 & 28,9 \\
\hline Eylül & 22,9 & 20,2 & 19,5 & 20,1 & 13,5 & 30,7 & 12,7 & 29,3 \\
\hline Ekim & 19,7 & 20,7 & 13,9 & 20,9 & 8,9 & 31,4 & 8 & 30,0 \\
\hline Kasım & 14 & 22,4 & 9,3 & 21,0 & 7,2 & 31,7 & 5,5 & 31,8 \\
\hline Aralık & 9,6 & 23,4 & 6,3 & 22,5 & 6 & 32,4 & 5,1 & 32,4 \\
\hline
\end{tabular}

Afşin-Elbistan Termik Santralinde yanma ünitelerinde havaya $270-330 \mathrm{~m}^{3} / \mathrm{sn}$. toz, karbondioksit, azot oksit, partikül maddeler, kükürt dioksit gibi zararlı gazlar karışmakta ve tozda $\mathrm{Al}_{2} \mathrm{O}_{3}, \mathrm{CaO}_{2} \mathrm{Fe}_{2} \mathrm{O}_{3}$, $\mathrm{MgO}, \mathrm{Cl}, \mathrm{SO}_{3}$ vb. gibi bileşikler yer almaktadır. [10 ve 27].

Yapılan gözlemlerle bu bileşenler ve inorganik emisyonlar rüzgârın yönü ve hızına bağlı olarak çevreye, tarım ve ağaçlandırılmış arazilere çökmektedir.

Gaz-toz dumanı fidanların yaprak yüzeyinde kalın toz tabakası oluşturmakta geniş yapraklılardan yalancı akasya üzerinde nekroz şeklinde yanıklara neden olmaktadır. Bununda birinci derecede asit yağmurlarından kaynaklandığı ihtimal edilmektedir. Sonuçta bu yapraklar kuruyarak dökülür ve ağaçlar kuruyor. Yapılan gözlemlerde bir hektar araziye 20-27 yıl bundan önce dikilen yalancı akasıya fidanlarının ortalama \%36 kuruduğu veya kuruma belirtilerine sahip olduğu son 5-10 yıl bundan önce dikilen parsellerde ise bu rakamın \%18 olduğu kayıt edilmiştir. Her ne kadar fidanların (27-20 yıllık) kök kısmı $85-110 \mathrm{~cm}$. kadar derinliğe insede topraktaki nem oranının yetersizliği ağaçların kurumasını önlememekte ve yaprak oluşumunu hızlı bir şekilde sağlamamaktadır. Kontrol olarak hava akımından pek etkilenmeyen Çomüdüz köyünde yapılan gözlemlerde aynı yaş ve gelişmede olan yalancı akasya yaprakları üzerinde nekroz yanıklara rastlanmamış ve ağaçlarda sararıp, kuruma kayıt edilmemiştir.

Çalışma süresince ağaçlandırılmış parsellerde böcek faunası ve popülasyon düzeyi araştırılmıştır. Sonuçta karaçam ve yalancı akasya vs. fidanlarının çeşitli kısımlarından toplam 9 tür (Anthonomus rubi, Cetonia aurata, Cerambyx cerdo, Pyrrhalta lineola, Hylesinus vestitus, Conocephalus fuscus, Aphis craccivora, Cicadatra persica, Ecdytolopha insticiana) zararlı böcek toplanmıştır. Bu türlerde 5 takım, 8 familya ve 9 cinse dâhil olmakla, 27-20 yıllık fidanlıklarda daha sıkı rastlanmaktadır. Türlerin \%65'i yaprak, \%23'ü gövde ve \%12'si ise ağaçların kök kısmıyla beslenmektedir.

\section{Tartışma ve Sonuç}

Yapılan gözlemlerle zarar eşiği ve popülâsyon düzeyi bakımından böceklerin ağaçların gelişimi ve kurumasında pek tehdit oluşturmadığı ve ayrıca böcek faunanın tamamen formalaşmadığı tespit edilmiştir. Nitekim Kahramanmaraş Sütçü İmam Üniversitesi Fen-Edebiyat Fakültesi Biyoloji Bölümü öğre- 
tim üyeleri tarafından santral çevresi hafriyat topraklarında ağaçlandırılmış arazilerde 21 bitki, 38 hayvan, fungus ve bakteri türleri saptanmış ve faunanın belli bir zaman içerisinde daha da zenginleşeceğini kayıt etmişler [28].

Elde edilen verilere dayanarak karaçam ve yalancı akasyaların kurumasının 1. derecede toprağın fiziko-kimyasal yapısından kaynaklandığı, yani toprakta ağır metal ve kireç oranının yüksek, organik bileşiklerin ise düşük olması ayrıca yazın toprakta yeterli miktarda nemliğin bulunmaması ve ilavetende asit yağmurlarının etkisi ile yaprakların sararıp dökülmesi ve bunun sonucunda da özellikle yalancı akasyaların kurumasına neden olduğu ihtimal edilmektedir

Nitekim Karaca ve arkadaşları, Seyitömer ve Afşin-Elbistan Termik Santralleri çevre topraklarında Ni ve Cr kapsamlarının standart değerlerinin üstünde olduğunu, özelliklede santralden uzaklaştıkça bu değerlerin arttığını tespit etmişler [29].

Birçok araştırmacılar Afşin-Elbistan Termik Santralinden kaynaklanan emisyonların hâkim rüzgâr yönündeki alanlarda ağır metal içeriklerinin yüksek olduğunu ve $\mathrm{SO}_{2}, \mathrm{CO}_{2}$ ve $\mathrm{NO}_{\mathrm{x}}$ gibi kirletici gazların Eucalyptus camaldulensis ve Morus alba ağaç türlerine olumsuz etkide bulunduğunu belirtmektedir. [26 ve 30].

Önleyici tedbir olarak dikim sırasında kuraklığa devamlı fidan çeşitlerine (örneğin; iğde, akçaağaç, dişbudak) daha ağırlık verilmesine ve mevcut ağaçlandırılmış arazilerde de nemliğin düşük olmasından dolayı yaz aylarında en azından 2-3 defa periyodik olarak sulanması gerekmektedir.

\section{Kaynaklar}

[1] Koç E., Şenel M. C. 2013. "Dünyada ve Türkiye'de Enerji Durumu - Genel Değerlendirme," Mühendis ve Makine, 54, 639, 32-44.

[2] Sarıül M. 1991. Hava Kirliliğinin Muğla-Yatağan Yöresinde Orman Toprağı ve Ağaçları Üzerine Etkisi. Ormancilık Araştırma Enstitü Teknik Bülten, No. 217-248.

[3] Haktanır K., Sözüdoğru Ok, S., Karaca A., Arcak S., Çimen, F., Topçuoğlu, B., Türkmen, C., Yıldız, H. 2010. Muğla-Yatağan Termik Santrali Emisyonlarının Etkisinde Kalan Tarım ve Orman Topraklarının Kirlilik Veri Tabanının Oluşturulması ve Emisyonların Vejetasyona Etkilerinin Araştııılması. Ankara Üniversitesi Çevre Bilimleri Dergisi 2 (1): 13-30.

[4] Taşkın Ö. 1998. Uçucu Kül Ve Bazı Organik Materyallerin Toprak Biyolojik Aktivitesi Üzerine Etkileri. Ankara Üniversitesi Fen Bilimleri Enstitüsü Toprak Anabilim Dalı Yüksek Lisans Tezi, $52 \mathrm{~s}$, Ankara.

[5] Güleç N., Tuncel G., Erler, A., Çancı, B., Hamzaoğlu A., Arcasoy, A., 1999. "Seyit Ömer Termik Santrali Küllerinin Çevreye Etkisinin İncelenmesi", Tübitak, Ankara.

[6] Baba A., Kaya A., Birsoy, Y.K. 2003. The Effect of Yatağan Thermal Power Plant (Muğla Turkey) on The Quality of Surface and Ground Waters, Water, Air, and Soil Pollution 149: 93111.

[7] Karaca A., Türkmen C., Arcak S., Haktanır K., Topçuoğlu B. ve Yıldız H., 2005. Çayırhan Termik Santralı Emisyonlarının Yöre Topraklarının Bazı Ağır Metal ve Kükürt Kapsamlarına Etkilerinin Belirlenmesi. Ankara Üniversitesi Çevre Bilimleri Dergisi, 1 (1): 17-25. 
[8] Karakurt H. 2004. Ege Bölgesinde Açık Kömür İşletmesi ve Toprak Döküm Alanlarındaki Ekolojik Şartlar ile Bu Alanlara Uygun Ağaçlandırma Tekniklerinin ve Ağaç Türlerinin Belirlenmesi. Ege Ormancılık Araştırma Müdürlüğü. Teknik Bülten. İzmir. 72 s.

[9] Zengin M., Oğuz H., 2012. Afşin-Elbistan İlçeleri Potansiyel Orman Alanlarının Belirlenmesi, KSÜ Doğa Bilimleri Dergisi Özel Sayl, Kahramanmaraş. s, 62-70.

[10] Anonim 2013, Afşin Elbistan Termik Santrali İşletme Müdürlüğünün yıllık raporu, 36 sayfa.

[11] Goncaloğlu B.İ., Ertürk F., Ekdal A., Termik Santrallerle Nükleer Santrallerin Çevre Etki Değerlendirmesi Açısından Karşılaştırılması, Ekoloji Çevre Dergisi, 9, 34, 9-14, 2000.

[12] Çepel N. 2006. Toprak Kirliliği ve Ekolojik Önemi. Türkiye Erozyonla Mücadele, Ağaçlandırma ve Doğal Varlıkları Koruma Vakfı Yayınları CDesi Konu 11.

[13] Karagöktaş M., 2012. Afşin-Elbistan Termik Santrali'nin Çevreye Olan Olası Etkisinin Belirlenmesi, Kahramanmaraş Sütçü İmam Üniversite Fen Bilimleri Enstitüsü Toprak Bilimi ve Bitki Besleme Ana Bilim Dalı, Yüksek Lisans Tezi, Kahramanmaraş s, 33.

[14] Akbay C., Dikici H., Arı H., Bilgiç A., 2011. "Afşin-Elbistan Termik Santrali’nin Neden Olduğu Çevre Kirliliğinin Ekonomik Analizi", TÜBİTAK Kahramanmaraş.

[15] Kahraman Y. 2011. Afşin-Elbistan Termik Santrali Küllerinin Tarımda Kullanım Olanakları, Kahramanmaraş Sütçü İmam Üniversitesi Fen Bilimleri Enstitüsü Toprak Bilimi ve Bitki Besleme Anabilim Dall, Yüksek Lisans Tezi, Kahramanmaraş. s, 48.

[16] Anonim 2012: Afşin-Elbistan A Termik Santrali İşletme Müdürlüğü faaliyet raporu s, 4.

[17] Demiralay İ. 1993. Toprak Fiziksel Analizleri. Atatürk Üniversitesi Ziraat Fakültesi No.143, Erzurum

[18] Öztan B., Ülgen, H. 1961. Saturasyon macununda ve ekstraktında tuz tayinleri. Toprak ve Gübre Araştırma Enstitüsü Müdürlüğü Yayınları, Teknik Yayın No 7, Ankara

[19] Black C.A. 1965. Methods of Analysis Part I. Amer. Soc. of Agron. Wisconsin-USA.

[20] Loeppert R.H., Suarez, D.L. 1996. Carbonate and Gypsum. p 437-475. In D.L. Sparks (ed) Method of Soil Analysis: Chemical Methods. Part 3. SSSA, Madison, WI.

[21] Jakson M. L. 1962. Soil chemical analysis. Prentice-Hall, Inc. Nem York.

[22] Helmke P.A., Sparks, D.L. 1996. Lithium, Sodium,Potassium,Rubidium, and Cesidium.P: 51575. Ġn D.L. Sparks (ed) Method of Soil Analysis: Chemical Methods. Part 3. SSSA, Madison, WI.

[23] Kuo S. 1996. Phosphorus. P: 869-921. In D.L.Sparks (ed) Method of Soil Analysis: Chemical Methods. Part 3. SSSA, Madison, WI.

[24] Loeppert R.H., Inskeep W.P. 1996. Iron. p 639-665. In D.L. Sparks (ed) Method of Soil Analysis: Chemical Methods. Part 3. SSSA, Madison, WI

[25] Çepel N. 1985. Toprak Fiziği, İstanbul Üniversitesi, Orman Fakültesi Yayınları, İ.Ü. Yayın No: 3313, O.F. Yayın No: 374, İstanbul.

[26] Aydemir G. 2008. Afşin-Elbistan Termik Santrali Emisyonlarının Yöre Topraklarına Etkilerinin Belirlenmesi, Yüksek Lisans Tezi, Ankara. s, 112

[27] Ural S. 2005, Comparison of Fly Ash Properties from Afsin-Elbistan Coal Basin,Turkey, Journal of Hazardous Materials B119, 85-92. 
[28] Bahadıroğlu C., 2003. Afşin-Elbistan Linyit İşletmesinde Hafriyat Topraklarda Biyosenozun Oluşumu. TÜBİTAK TOGTAG TRAP-2526 nolu Proje.

[29] Karaca A., Turgay O.C., Karaca S., Sağlam M., Türkmen F., Deviren S., Türkmen, N. 2007. Seyitömer Termik Santrali Emisyonlarının Çevre Toprakları Üzerine Etkiler. Proje, Yayınlanmamış, Ankara.

[30] Deniz M., 2010. Termik Santral Kaynaklı Hava Kirliliğinin Bitkilerdeki Mineral Beslenme ve Antioksidatif Savunma Mekanizmasına Etkisi Çukurova Üniversitesi Fen Bilimleri Enstitüsü Biyoloji Ana Bilim Dalı Doktora Tezi, Adana s, 175. 